\title{
Use of Bacterial Cellulose from Gluconacetobacter hansenii NOK21 as a Proton-permeable Membrane in Microbial Fuel Cells
}

\author{
Young Hwan Ko*, Hwa Jeong Oh and Hyun Jung Lee \\ Department of Food Bioengineering, Jeju National University, Jejudo, Korea
}

\begin{abstract}
An acetic acid bacterium NOK21 from the pellicle on the surface of rancid wine was isolated and identified as Gluconacetobacter hansenii based on morphological, physiological, and genetic characteristics. When the bacterial isolate was grown in static broth containing ethanol, a maximum pellicle concentration of $5.2 \mathrm{~g} / \mathrm{l}$ was obtained at $3 \%$ ethanol concentration and a maximum acidity of $3.97 \%$ was reached at $5 \%$ ethanol concentration. At ethanol concentrations higher than $6 \%$, no bacterial growth was observed. Analysis with solid state ${ }^{13} \mathrm{C}-\mathrm{NMR}$ spectroscopy showed that the pellicle from the NOK21 culture was composed of a relatively pure cellulose polymer and had a few carboxylate (COO-) groups. Also, observation of the pellicle with SEM revealed a multi-layer network structure where nano-diameter cellulose fibers were tangled together at random. The pellicle cellulose polymer was used as a proton-permeable membrane in a microbial fuel cell (MFC) and had about a 3-fold higher efficiency for electric power generation than a cation exchange membrane Neosepta CMX. Moreover, electric power was generated stably at $150-200 \mathrm{~mW} / \mathrm{m}^{2}$ per anode surface area. These results suggest that the microfibril cellulose membrane from the NOK21 culture may be suitable for use as an alternative to expensive proton exchange membranes in MFCs.
\end{abstract}

Keywords: Bacterial cellulose; Gluconacetobacter hansenii; Microbial fuel cell; Acidity; Ethanol

\section{Introduction}

While plant cellulose is a heteropolymer composed of mainly cellulose, hemicellulose, and lignin, bacterial cellulose (BC) is a relatively pure homopolymer of $\beta$-1.4-bonded glucose. The three dimensional structure of $\mathrm{BC}$ is a microfibril network composed of nano-diameter cellulose fibers [1].

It has been reported that bacterial species belonging to Acetobacter [2], Agrobacterium [3], or Rhizobium [4] produce cellulose. Among those cellulose producers, aerobic acetic acid bacteria that make a pellicle on the surface of fermentation broth have been studied for a long time and used for beverage manufacture such as for Kombucha [5,6]. Ninety years after Brown [7] reported for the first time in 1886 that the pellicle on an acetic ferment had a cellulose component, Brown et al. [8] showed that the pellicle formed by Acetobacter xylinum on the surface of a liquid culture had a microfibril cellulose assembly. Since then there have been extensive studies on synthesis mechanism and production $[9,10]$ as well as on use and application [11-13] of BC.

Meanwhile microbial fuel cell (MFC) is a bio-electrochemical system in which biological energy generated by oxidation of organic and inorganic matter by microorganisms is converted into electrical energy. Basically an MFC consists of anode and cathode chambers with a proton-permeable membrane between them. Anaerobic bacteria grow in the anode chamber by oxidizing organic matter, and the protons and electrons produced concomitantly from oxidation are transferred through a proton-permeable membrane and an external circuit respectively to the cathode chamber [14]. The proton-permeable membrane should have micro-pores that permit proton passage but restrict passage of other materials such as cations and anions. Although it is generally recommended to use a proton exchange membrane (PEM) as the proton-permeable membrane, PEMs are costly because of high technology requirements. A cation exchange membrane (CEM) is a cheap alternative to a PEM, but it allows the passage of other cations as well as protons $[15,16]$.
In this study, a cellulose-producing bacterium was isolated from the pellicle on the surface of rancid wine and identified. Its cellulose pellicle was investigated to determine its physico-chemical structure and properties with the aim of using it as a proton-permeable membrane in MFCs.

\section{Materials and Methods}

\section{Isolation and cultivation of a pellicle-producing bacterium}

A bacterium was isolated from a slippery pellicle formed on the surface of rancid wine and cultured using Schramm-Hestrin (SH) medium $(20 \mathrm{~g} / \ell$ dextrose, $5 \mathrm{~g} / \ell$ yeast extract, $5 \mathrm{~g} / \ell$ bactopeptone, $2.7 \mathrm{~g} / \ell$ $\mathrm{Na}_{2} \mathrm{HPO}_{4}, 1.15 \mathrm{~g} / \ell$ citric acid) [17] at an incubation temperature of $28^{\circ} \mathrm{C}$. Solid agar plate was used for isolation of pure colonies, and cycloheximde $(50 \mu \mathrm{g} / \mathrm{ml})$ was added whenever necessary to prevent fungal contamination.

To examine the effect of ethanol on bacterial growth, ethanol (95\%) was added to the $\mathrm{SH}$ medium after sterilization to provide final ethanol concentrations of $1 \% \sim 8 \%$. Then $100 \mathrm{ml}$ of each SH medium containing ethanol was put separately into Erlenmeyer flasks and $1 \mathrm{ml}$ of healthy bacterial culture was added to each flask for inoculation. Next, the medium was incubated statically without shaking.

\section{S-rRNA gene sequencing}

Nucleotide sequences of 16S-rRNA gene from the bacterial isolate

*Corresponding author: Young Hwan Ko, Department of Food Bioengineering Jeju National University, Jejudo, Korea, Tel: +82-64-754-3616; Fax: +82-64-7553601; E-mail: yhkbl@jejunu.ac.kr

Received March 19, 2015; Accepted April 29, 2015; Published May 06, 2015

Citation: Ko YH, Oh HJ, Lee HJ (2015) Use of Bacterial Cellulose from Gluconacetobacter hansenii NOK21 as a Proton-permeable Membrane in Microbial Fuel Cells. J Microb Biochem Technol 7: 145-151. doi:10.4172/19485948.1000196

Copyright: (c) $2015 \mathrm{Ko} \mathrm{YH}$, et al. This is an open-access article distributed under the terms of the Creative Commons Attribution License, which permits unrestricted use, distribution, and reproduction in any medium, provided the original author and source are credited 
were determined and compared for its identification. Total genomic DNA was purified from the bacterial cells. Partial 16S-rRNA gene was amplified with PCR (GeneAmp ${ }^{\circ}$ PCR System 9700, Applied Biosystems) using universal primers 27F (5'-AGA GTT TGA TCC TGG CTC AG-3') and 1492R (5'-GGT TAC CTT GTT ACG ACT T-3'). The PCR running conditions were as follows: $15 \mathrm{~min}$ at $95^{\circ} \mathrm{C}$ (denaturation), $20 \mathrm{sec}$ at $95^{\circ} \mathrm{C}$, $40 \mathrm{sec}$ at $50^{\circ} \mathrm{C}$ (annealing), $1 \mathrm{~min} 30 \mathrm{sec}$ at $72^{\circ} \mathrm{C}$ ( Taq DNA polymerase reaction), $5 \mathrm{~min}$ at $72^{\circ} \mathrm{C}, 30$ cycles. The PCR product was purified by a PCR purification kit (SolGent Co., Ltd., Daejeon, Korea) and confirmed on $1 \%$ agarose gel. The purified PCR product of 16S-rRNA gene was fluorescence-labelled with a Bigdye Terminator Cycle Sequencing Ready Reaction Kit (Applied Biosystems, Foster City, CA, USA) and the residual unreacted ddNTP was removed by ethanol precipitation of the DNA. The DNA was redissolved in deionized formamide and run on an ABI XL DNA Analyzer (Applied Biosystems) equipped with capillary electrophoresis and a laser detector for automated sequencing. Partial sequences of $1380 \mathrm{bp}$ out of the total $16 \mathrm{~S}$ rRNA gene were determined and a BLAST search using the GenBank database of the National Center for Biotechnology Information (NCBI) was carried out for comparison and homology search. The partial 16S-rRNA gene sequences of our bacterial isolate NOK21 were submitted to the Genbank of the NCBI (accession number KP690078).

\section{Physiological characterization}

Physiological characteristics of the bacterial isolate were determined using an Analytical Profile Index (API) 50CHB/E kit (Biomerieux Co., France). The kit was handled according to the procedures recommended by the supplier.

\section{Acidity measurement}

Bacterial culture filtrate was diluted 10-fold with distilled water, and then $20 \mathrm{ml}$ of the diluted filtrate was titrated with $0.1 \mathrm{~N} \mathrm{NaOH}$ in the presence of phenolphthalein as an indicator. Acidity was calculated as equivalents of acetic acid as follows [18]: Acidity $(\mathbf{\%})=\mathbf{V} \times \mathbf{A} \times \mathbf{D} \times(\mathbf{1} / \mathbf{S}) \times \mathbf{1 0 0}$, where $\mathrm{V}$, volume of $0.1 \mathrm{~N} \mathrm{NaOH}$ added $(\mathrm{ml})$; $\mathrm{A}$, an equivalent of acetic acid to $1 \mathrm{ml}$ of $0.1 \mathrm{~N} \mathrm{NaOH}(0.006 \mathrm{~g})$; $\mathrm{D}$, dilution rate $(\times 10)$; $\mathrm{S}$, volume of sample titrated $(20 \mathrm{ml})$.

\section{Preparation of pellicle membrane}

Insoluble pellicle membrane on the surface of the bacterial static culture was harvested and soaked in $0.5 \mathrm{M} \mathrm{NaOH}$ at $90^{\circ} \mathrm{C}$ for $1 \mathrm{hr}$ and then washed with distilled water by soaking and decanting until the $\mathrm{pH}$ of the drained water reached neutral [19]. The cleaned pellicle biopolymer was dried at $105^{\circ} \mathrm{C}$ until constant weight was obtained, and used directly as a proton-permeable membrane in MFC.

\section{Solid state ${ }^{13} \mathrm{C}-\mathrm{NMR}$ spectroscopy}

The bacterial pellicle membrane was analysed by solid state ${ }^{13} \mathrm{C}-\mathrm{NMR}$ spectroscopy [19]. The solid-state cross-polarization magicangle-spinning (CP MAS) experiments were performed on a 400 $\mathrm{MHz}$ Avance $\mathrm{II}^{+}$Bruker solid state NMR spectrometer. The operation conditions were as follows: rotor spinning rate, $8 \mathrm{kHz}$; delay time, 3 sec; contact time, $2 \mathrm{~ms}$; radio frequency, $100.623 \mathrm{MHz}$; calibration reference, tetramethylsilane.

\section{Scanning electron microscopy}

The pellicle structure was examined by Scanning Electron Microscopy (SEM). The pellicle was harvested from the bacterial culture and dehydrated sequentially in a graded series of ethanol for 10 min each: $50 \%$ ethanol, $70 \%$ ethanol, $90 \%$ ethanol, $95 \%$ ethanol, and
$100 \%$ ethanol. After dehydration, the residual ethanol in the pellicle was removed by soaking in a graded series of isoamyl acetate in ethanol for 10 min each: $30 \%$ isoamyl acetate, $50 \%$ isoamyl acetate, $70 \%$ isoamyl acetate, and $100 \%$ isoamyl acetate. Finally, the pellicle specimen was critical point dried. The dried specimen was mounted on studs, sputter coated with platinum, and observed under a Field Emission SEM (JSM6700F, JEOL Ltd, Japan).

\section{Manufacture and operation of MFC}

Two sets of MFCs were manufactured in a two-chamber system by using acrylic glass as the main material (Figure 1). The total volume was $80 \mathrm{~L}$ with the anode and cathode chambers occupying $45 \mathrm{~L}$ and $35 \mathrm{~L}$ respectively. For the installation and replacement of the protonpermeable membrane, a cylindrical pipe with diameter $9 \mathrm{~cm}$ was mounted in the center of the partition that divides the chambers. The working volumes were $20.7 \mathrm{~L}$ for the anode chamber and $13.8 \mathrm{~L}$ for the cathode chamber. Carbon plates with a surface area of $460 \mathrm{~cm}^{2}$ each were immersed in both anode and cathode chambers, one for each chamber, which were connected externally by copper wire in the middle of which $1 \Omega$ of resistance was mounted. The anode chamber was sealed tight to maintain an anaerobic condition whereas the cathode chamber was ready for aeration to maintain an aerobic condition. The bacterial cellulose pellicle (basis weight, $0.0025 \mathrm{~g} / \mathrm{cm}^{2}$ ) and a cation exchange membrane Neosepta CMX (basis weight, $0.0050 \mathrm{~g} / \mathrm{cm}^{2}$; Astom Co., Japan) were compared with each other for use as a proton-permeable membrane in MFCs. Neosepta CMX as a cation exchanger has a sulfonate $\left(-\mathrm{SO}_{3}^{-}\right)$functional group and strong physical strength, and it has been widely used in water treatment such as desalting sea water. Deposited soil at the bottom of a small lake, where microbial consortia was maintained under anaerobic condition, was added as a microbial oxidizer to the anode chamber filled with fresh water and glucose was added as an energy source at a final concentration of $2 \%$, whereas only

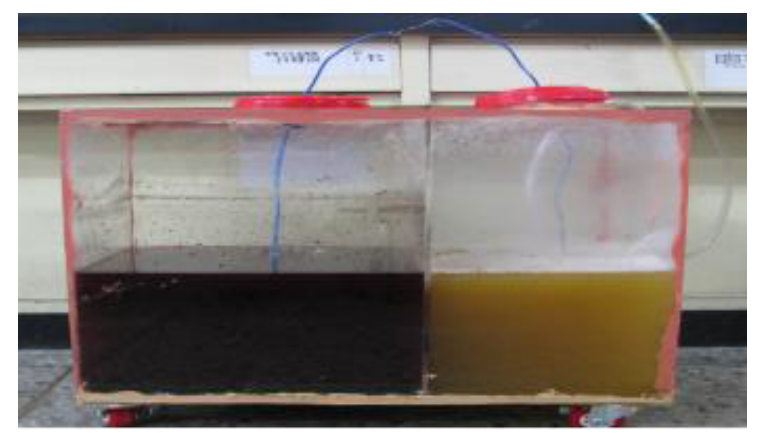

(B)

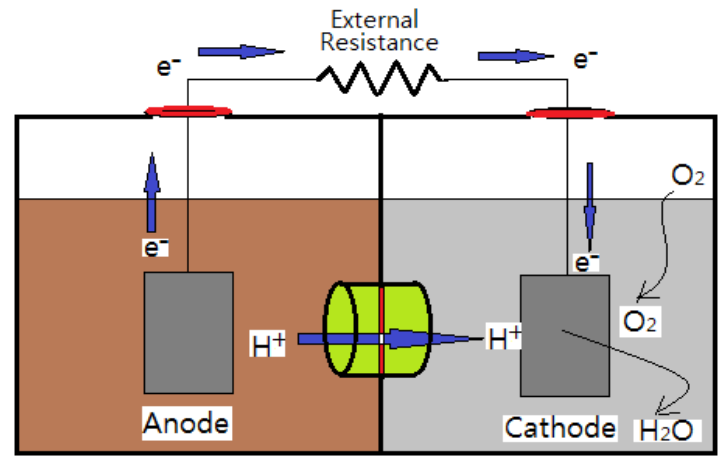

Figure 1: Microbial fuel cell (MFC) manufactured in this study. (A, MFC set in operation; B, Schematic diagram of MFC). 
Citation: Ko YH, Oh HJ, Lee HJ (2015) Use of Bacterial Cellulose from Gluconacetobacter hansenii NOK21 as a Proton-permeable Membrane in Microbial Fuel Cells. J Microb Biochem Technol 7: 145-151. doi:10.4172/1948-5948.1000196

fresh water was added to the cathode chamber. The microbial flora was acclimated to the new growth environment for at least 10 days before data acquisition.

\section{Results and Discussion}

\section{Bacterial isolation, cultivation, and identification}

A bacterial strain NOK21 was isolated from the thick and slippery pellicle on the surface of rancid wine. On SH agar plate, it made a pale, white-colored and smooth to rough colony. The colony was circular in shape with entire margin and convex elevation. The bacterial cell had a rod shape and was strictly aerobic, catalase-positive, and gram-negative.

The strain NOK21 formed a pellicle membrane on the surface of SH liquid medium in aerobic standing culture. The pellicle thickened as incubation time passed and finally submerged. Upon submergence of the pre-existing pellicle, a new pellicle began to appear on the surface and grew thick. The thickened pellicle submerged again. This kind of growth cycle, appearance and submergence of the pellicle, was repeated several times.

An assimilation test of several carbon sources by the strain NOK21 showed that the bacterium utilized $\mathrm{D}$-glucose, $\mathrm{N}$-acetylglucosamine, potassium gluconate, 2-keto-gluconate, and 5-keto-gluconate (Table 1). The physiological property of gluconate assimilation was consistent with that of Gluconacetobacter hansenii [20].

Partial 16S-rRNA gene sequences of NOK21 were evaluated for the percent homology to other gene sequences stored in the Genbank database of the NCBI. Distances were calculated by the UPGMA method and a phylogenetic tree was constructed by multiple alignment (Figure 2). Most strains that showed above $99.7 \%$ similarity to NOK21 belonged to $G$. hansenii such as $G$. hansenii NBRC 14820, G. hansenii NBRC 14817, G. hansenii NBRC 14816, G. hansenii NBRC 105051, G. hansenii NCIB 8746, and G. kombuchae LMG23726 . G. kombuchae

\begin{tabular}{|c|c|c|c|c|}
\hline Carbon source & D-glucose & potassium gluconate & 2-keto-gluconate & 5-keto-gluconate \\
\hline Result $^{\star}$ & positive & positive & positive & positive \\
\hline
\end{tabular}

* Determined by Analytical Profile Index (API) 50CHB/E kit.

Table 1: Utilization of various carbon sources by Gluconacetobacter species NOK21.

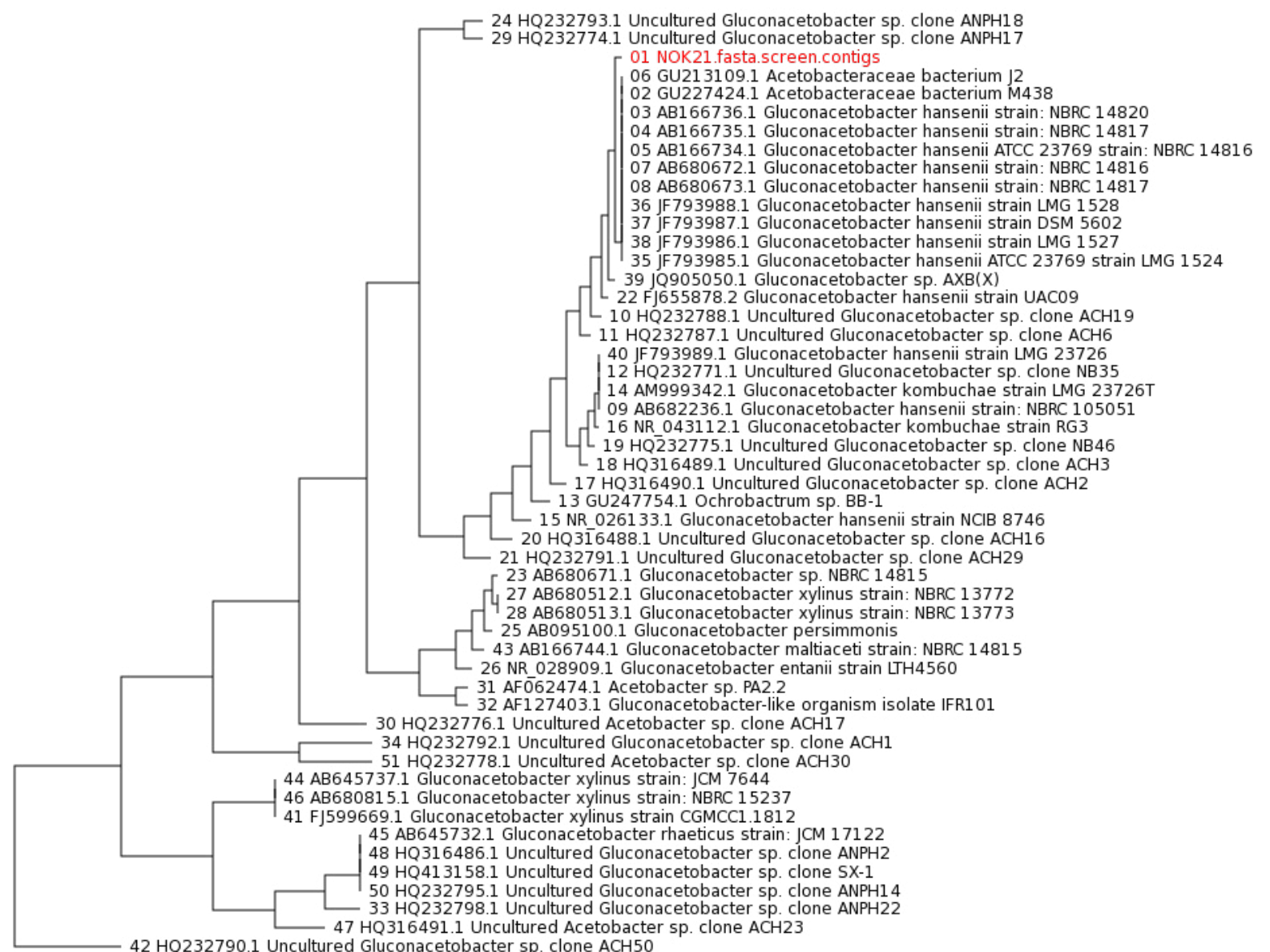

$42 \mathrm{HQ} 232790.1$ Uncultured Gluconacetobacter sp. clone ACH50

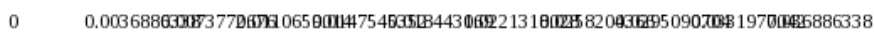

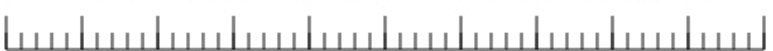

SolGent co., Ltd.

Figure 2: Phylogenetic tree of isolate NOK21 produced by comparing 1,380 bp partial sequences of the 16S-rRNA gene using the UPGMA method. (NOK21.fasta.screen.contigs, GenBank accession number KP690078). 
LMG23726 ${ }^{\mathrm{T}}$ is a pellicle-forming strain on liquid culture and has been used for the manufacture of tea Kombucha [19,21]. G. kombuchae was recently reclassified as $G$. hansenii [22]. Our bacterial isolate NOK21 is believed to be the same species as $G$. hansenii, which was reported to produce acetic acid through ethanol oxidation and to form a cellulose pellicle [23]

\section{Effect of ethanol concentration on bacterial growth}

NOK21 was expected to oxidize ethanol and produce acetic acid because it was isolated from a pellicle on the surface of rancid wine. Changes in acidity and pellicle synthesis in accordance with the ethanol concentration of SH medium were determined (Figure 3). The fastest bacterial growth was observed with $3 \%$ ethanol medium. Neither acid nor pellicle was produced at an ethanol concentration above $6 \%$ regardless of incubation time. The bacterium was unable to grow at ethanol concentrations higher than $6 \%$ because of toxicity. The maximum acidity of $3.97 \%$ was obtained with a $5 \%$ ethanol concentration after incubation for 15 days, while the amount of pellicle synthesized increased gradually and reached the highest concentration of $5.2 \mathrm{~g} / \ell$ with a $3 \%$ ethanol concentration after incubation for 15 days. The reason that acidity and pellicle synthesis increased in an ethanoldependent manner may be because of greater energy supply that accompanied ethanol oxidation. G. hansenii is known to be ethanoltolerant and to gain energy from ethanol oxidation [24]. These effects of ethanol on NOK21 growth support the finding that the bacterial isolate belongs to the acetic acid bacteria G. hansenii. Usha Rani et al. [25] also isolated from contaminated grape wine a strain of $G$. hansenii that produced a cellulose pellicle, and their strain produced $1.5 \sim 8.5 \mathrm{~g} / \mathrm{L}$ of cellulose polymer depending on culture conditions.

\section{Structure of pellicle membrane}

The physical make-up of the pellicle from the NOK21 culture was shown by scanning electron microscopy (Figure 4). The surface of the pellicle appears wrinkled but somewhat smooth (Figure 4A). Long fibers with diameters in the nano-range are woven into a network structure (Figure 4B). A longitudinal section of the pellicle shows the process of its formation, by which each unit membrane of the pellicle is
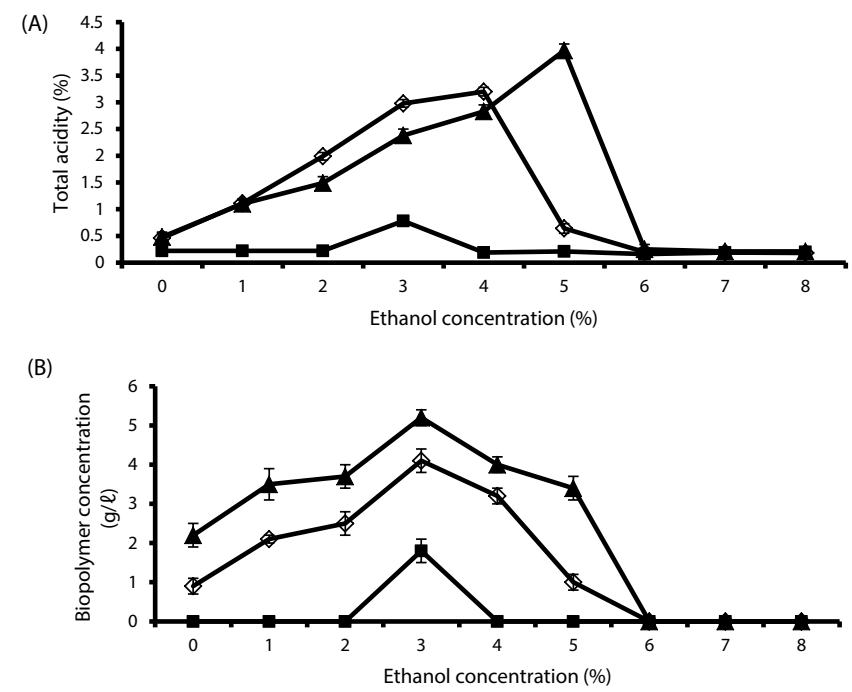

Figure 3: Changes in total acidity (A) and pellicle biopolymer concentration (B) in accordance with ethanol concentration during the cultivation of isolate NOK21 for $5(\mathbf{\bullet}), 10(\diamond)$, or 15 days $(\boldsymbol{\Delta})$.

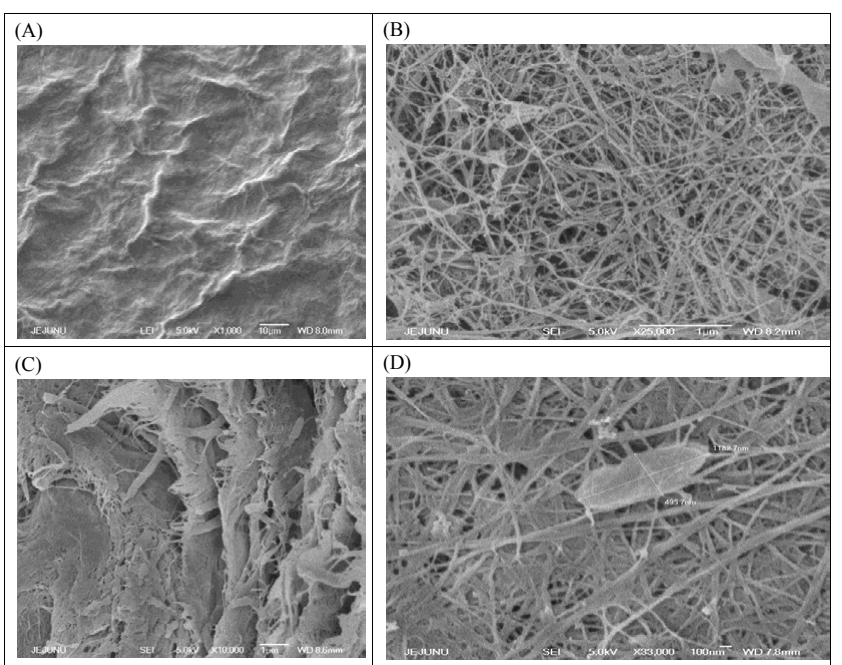

Figure 4: Scanning electron microscopy images of the cellulose pellicle synthesized by Gluconacetobacter hansenii NOK21.

( $A$ and $B$, Surface structures; C, Cross-sectional view; D, A bacterial cell on the pellicle).

synthesized in consecutive order and each newly synthesized membrane overlays the old one to form a thick and multilayered structure (Figure $4 \mathrm{C})$. The multi-layered network structure of the pellicle membrane is expected to have unique physical properties, such as high water-holding capacity, that differentiate it from a mono-layered membrane. The cells of NOK21 are rod-shaped with a dimension $1.2 \times 0.5 \mu \mathrm{m}$ (Figure $4 \mathrm{D}$ ). This pellicle structure of NOK21 is very similar to that of Gluconobacter xylinum [13].

The insoluble pellicle biopolymer was analyzed by solid state ${ }^{13} \mathrm{C}$-NMR spectroscopy to determine the carbon skeleton structure (Figure 5). As a reference, the ${ }^{13} \mathrm{C}-\mathrm{NMR}$ spectrum of absorbent cotton revealed only 6 carbons consisting of glucose [26-29], which proves that cotton is pure cellulose with glucose as a repeating unit (Figure $5 \mathrm{~A}) .{ }^{13} \mathrm{C}$-NMR spectroscopy of the pellicle polymer showed a nearly identical pattern to the cotton spectrum and that the pellicle was in an almost pure form as expected (Figure 5B). The short peak at 172 ppm corresponds to carboxylate carbon ( $\left.\mathrm{COO}^{-}\right)$[30], suggesting the presence of a small portion of free carboxyl groups in the pellicle. The presence of the carboxylate anion enables the pellicle to be used as a cation exchanger membrane or as a proton-permeable membrane.

\section{Application of pellicle membrane to MFC}

The pellicle cellulose was tested for its use as an alternative to the proton exchange membrane that lies between anode and cathode chambers. Proton permeability of the pellicle membrane was compared with that of Neosepta CMX by measuring electricity generated under the same conditions (Figure 6). During 18 days of operation of the MFC with an external resistance $1 \Omega$, the average current was $40 \mu \mathrm{A}$ with Neosepta CMX and $120 \mu \mathrm{A}$ with the pellicle membrane. The pellicle from the NOK21 culture was about three times more effective in electricity generation than the cation exchanger Neosepta CMX, which suggests that the former has proton permeability about three times higher than the latter. In addition to the cation exchange function of the carboxylate groups, the hydrogel properties of the pellicle are believed to promote proton transfer through the hydrogen bond network of the water molecules [31]. 
Citation: Ko YH, Oh HJ, Lee HJ (2015) Use of Bacterial Cellulose from Gluconacetobacter hansenii NOK21 as a Proton-permeable Membrane in Microbial Fuel Cells. J Microb Biochem Technol 7: 145-151. doi:10.4172/1948-5948.1000196

(A)

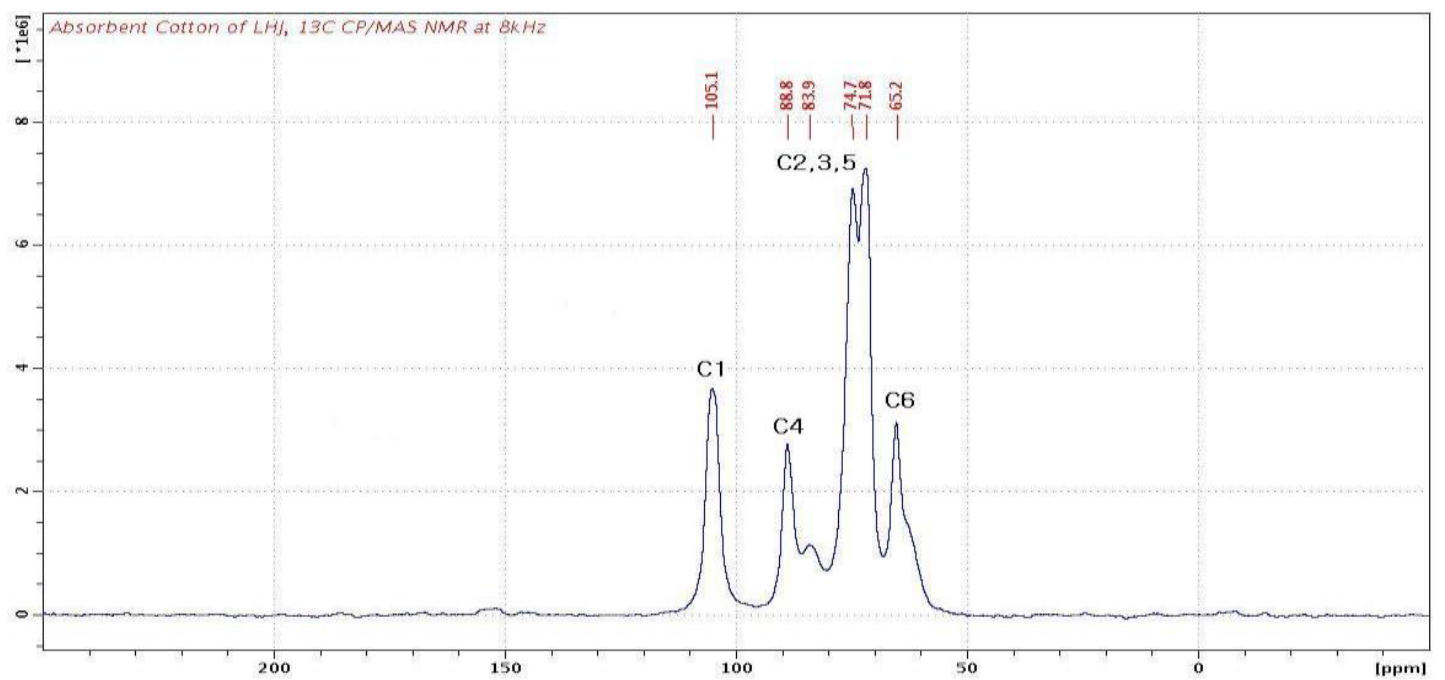

(B)

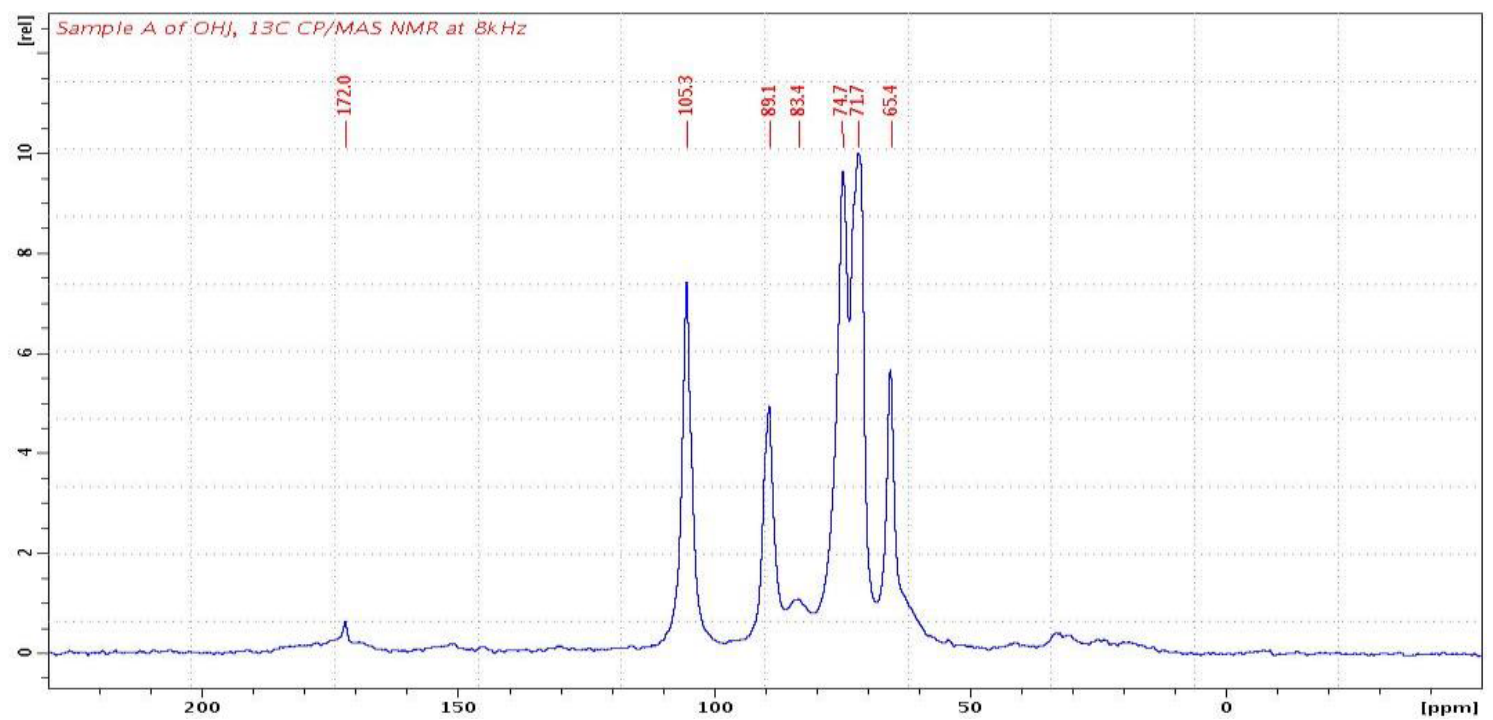

Figure 5: Solid state ${ }^{13} \mathrm{C}-\mathrm{NMR}$ spectra of absorbent cotton $(\mathrm{A})$ and the pellicle biopolymer synthesized by Gluconacetobacter hansenii NOK21 (B).

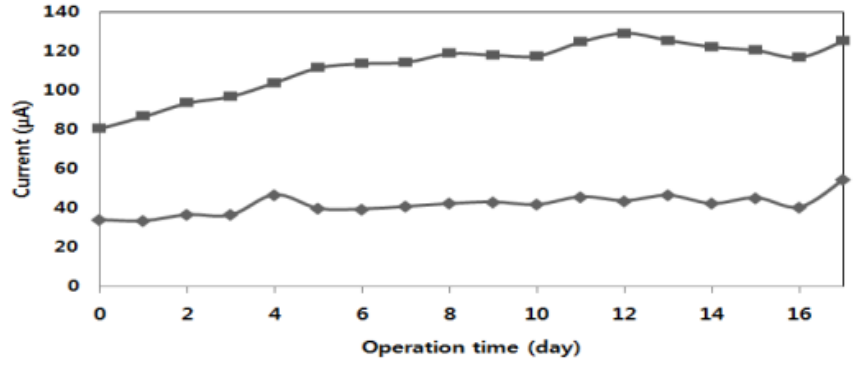

Figure 6: Changes of electric current in a microbial fuel cell using a cation exchanger resin (Neosepta CMX, $\bullet$ ) or a bacterial pellicle $(\mathbf{m})$ as a protonpermeable membrane.

Dissolved oxygen is required in the anode chamber where both protons and electrons meet oxygen molecules to produce water molecules. Cessation of aeration after 14 days of operation caused electricity generation to decrease continuously to reach $50 \%$ of the original level after 10 days, while resumption of aeration caused a voltage increase and restored the original level (Figure 7). The MFC equipped with the pellicle membrane was working normally.

Microbial oxidation of a substrate without oxygen in an anode chamber produces protons and electrons. Although it would be desirable to have microbes that can transfer electrons directly to the anode, most microbial cells are not able to do this. A redox mediator that could shuttle electrons between microbes and the anode was proven to accelerate production of electricity [32]. Neutral red as a redox mediator was expected to increase voltage generation in our MFC system, where many and unspecified bacteria were used for substrate oxidation. Neutral red is fat-soluble and binds well to cell membranes. Moreover it has a redox potential of $-325 \mathrm{mV}$, which is comparable to that of $\mathrm{NADH}(-320 \mathrm{mV})$ and facilitates mutual electron exchange.

The addition of neutral red $\left(\mathrm{C}_{15} \mathrm{H}_{17} \mathrm{ClN}_{4}\right.$, Sigma-Aldrich $)$ at a concentration of $1 \mu \mathrm{M}$ to the anode chamber enhanced electrical power generation (Figure 8). After addition of neutral red, electrical power 
Citation: Ko YH, Oh HJ, Lee HJ (2015) Use of Bacterial Cellulose from Gluconacetobacter hansenii NOK21 as a Proton-permeable Membrane in Microbial Fuel Cells. J Microb Biochem Technol 7: 145-151. doi:10.4172/1948-5948.1000196

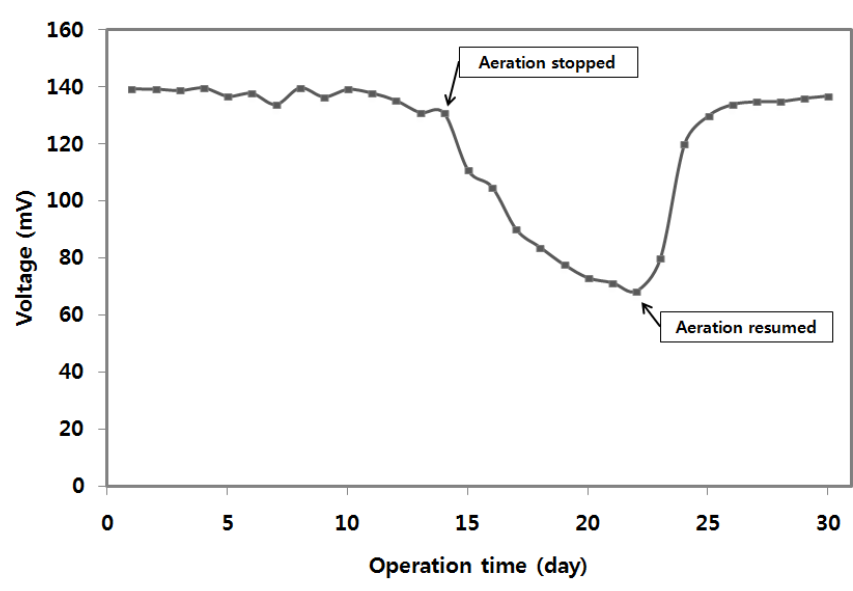

Figure 7: Changes of electric voltages in accordance with aeration of the cathode chamber of the microbial fuel cell using a bacterial pellicle as a protonpermeable membrane.

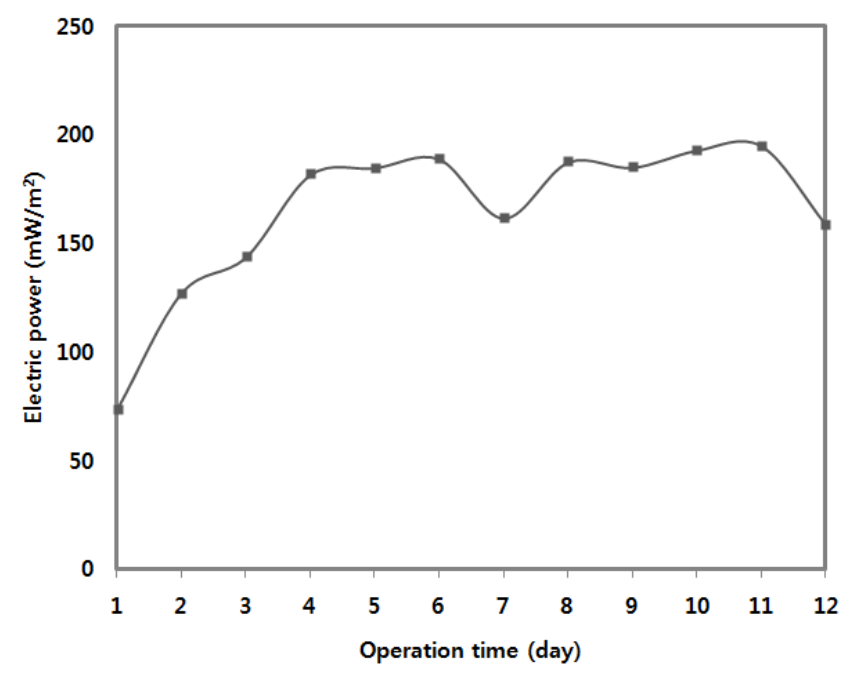

Figure 8: Effects of neutral red $(1 \mu \mathrm{M})$ on electric power generation in the microbial fuel cell using a bacterial pellicle as a proton-permeable membrane.

began to increase gradually for $4 \sim 5$ consecutive days and moved from $73 \mathrm{~mW} / \mathrm{m}^{2}$ to reach a maximum of $195 \mathrm{~mW} / \mathrm{m}^{2}$. The promotive effects of a redox mediator in an MFC system was also observed when a pure culture of Escherichia coli was used as an oxidizer [33].

Our MFC system with the bacterial pellicle as a proton-permeable membrane generated around $150 \sim 200 \mathrm{~mW} / \mathrm{m}^{2}$ of electric power (Figure 8 ). This power density does not differ markedly from data obtained by other researchers [34]. In case of the use of carbon plates as electrodes, glucose as a substrate, and a proton exchange membrane or a cation exchange membrane as a proton-permeable membrane, power density within the range of $18 \sim 3,600 \mathrm{~mW} / \mathrm{m}^{2}$ was obtained.

Our data demonstrated for the first time that a $\mathrm{BC}$ membrane may be suitable for use in MFC systems as an alternative to proton exchange membranes.

\section{References}

1. Ross P, Mayer R, Benziman M (1991) Cellulose biosynthesis and function in bacteria. Microbiol Rev 55: 35-58
2. Römling $U$ (2002) Molecular biology of cellulose production in bacteria. Res Microbiol 153: 205-212.

3. Matthysse AG, Thomas DL, White AR (1995) Mechanism of cellulose synthesis in Agrobacterium tumefaciens. J Bacteriol 177: 1076-1081.

4. Ausmees $N$, Jonsson $H$, Höglund S, Ljunggren $H$, Lindberg $M(1999)$ Structura and putative regulatory genes involved in cellulose synthesis in Rhizobium leguminosarum bv. trifolii. Microbiology $145:$ 1253-1262.

5. Bauer-Petrovska B, Petrushevska-Tozi L (2000) Mineral and water soluble vitamin content in the Kombucha drink. Int J Food Sci Technol 35: 201-205.

6. Chen C, Liu BY (2000) Changes in major components of tea fungus metabolites during prolonged fermentation. J Appl Microbiol 89: 834-839.

7. Brown AJ (1886) On an acetic ferment which forms cellulose. J Chem Soc 49 172-186.

8. Brown RM Jr, Willison JH, Richardson CL (1976) Cellulose biosynthesis in Acetobacter xylinum: visualization of the site of synthesis and direct measurement of the in vivo process. Proc Natl Acad Sci U S A 73: 4565-4569.

9. Iguchi M, Yamanaka S, Budhiono A (2000) Bacterial cellulose-a masterpiece of nature's arts. J Mater Sci 35: 261-270.

10. Keshk SM (2014) Bacterial cellulose production and its industrial applications. J Bioproces Biotechniq 4: 1-10.

11. Chawla PR, Bajaj IB, Survase SA, Singhal RS (2009) Microbial cellulose: Fermentative production and applications. Food Technol Biotechnol 47: 107124

12. Jonas R, Farahc LF (1998) Production and application of microbial cellulose. Polym Degrad Stab 59: 101-106.

13. Retegi A, Gabilondo N, Pena C, Zuluaga R, Castro C, et al. (2010) Bacterial cellulose films with controlled microstructure-mechanical property relationships. Cellulose 17: 661-669.

14. Singh D, Pratap D, Baranwal Y, Kumar B, Chaudhary RK (2010) Microbial fuel cells: A green technology for power generation. Ann Biol Res 1: 128-138.

15. Choi TH, Kim HW, Park HB (2010) Current research trends in microbial fuel cell based on polymer electrolyte membranes. Membr J 20: 173-184.

16. Logan BE, Hamelers B, Rozendal R, Schröder U, Keller J, et al. (2006) Microbia fuel cells: methodology and technology. Environ Sci Technol 40: 5181-5192.

17. HESTRIN S, SCHRAMM M (1954) Synthesis of cellulose by Acetobacter xylinum. II. Preparation of freeze-dried cells capable of polymerizing glucose to cellulose. Biochem J 58: 345-352.

18. Lee OS, Jang SY, Jeong YJ ( 2003) Effect of ethanol on the production of cellulose and acetic acid by Gluconacetobacter persimmonensis KJ145. J Korean Soc Food Sci Nutr 32: 181-184.

19. Nguyen VT, Flanagan B, Gidley MJ, Dykes GA (2008) Characterization of cellulose production by a Gluconacetobacter xylinus strain from Kombucha Curr Microbiol 57: 449-453.

20. Lisdiyanti P, Navarro RR, Uchimura T, Komagata K (2006) Reclassification of Gluconacetobacter hansenii strains and proposals of Gluconacetobacter saccharivorans sp. nov. and Gluconacetobacter nataicola sp. nov. Int J Syst Evol Microbiol 56: 2101-2111.

21. Dutta D, Gachhui R (2007) Nitrogen-fixing and cellulose-producing Gluconacetobacter kombuchae sp. nov., isolated from Kombucha tea. Int J Syst Evol Microbiol 57: 353-357.

22. Cleenwerck I, Wachter MD, Gonzalez A, Vuyst LD, Vos PD (2009) Differentiation of species of the family Acetobacteraceae by AFLP DNA fingerprinting: Gluconacetobacter kombuchae is a later heterotypic synonym of Gluconacetobacter hansenii. Int J Syst Evol Microbiol 59: 1771-1786.

23. Iyer PR, Geib SM, Catchmark J, Kao TH, Tien M (2010) Genome sequence of a cellulose-producing bacterium, Gluconacetobacter hansenii ATCC 23769. J Bacteriol 192: 4256-4257.

24. Garrity G, Brenner DJ, Staley JT, Krieg NR, Boone DR, et al. (2005) The proteobacteria (Part C). In: Garrity G, Brenner DJ, Krieg NR, Staley JT (ed) Bergey's Manual of Systematic Bacteriology. (2nd edn), Springer, New York.

25. Rani MU, Appaiah KA (2013) Production of bacterial cellulose by Gluconacetobacter hansenii UAC09 using coffee cherry husk. J Food Sci Technol 50: 755-762. 
Citation: Ko YH, Oh HJ, Lee HJ (2015) Use of Bacterial Cellulose from Gluconacetobacter hansenii NOK21 as a Proton-permeable Membrane in Microbial Fuel Cells. J Microb Biochem Technol 7: 145-151. doi:10.4172/1948-5948.1000196

26. Atalla RH, Vanderhart DL (1999) The role of solid state 13C NMR spectroscopy in studies of the nature of native celluloses. Solid State Nucl Magn Reson 15: $1-19$.

27. Kono H, Erata T, Takai M (2002) CP/MAS (13)C NMR study of cellulose and cellulose derivatives. 2. Complete assignment of the (13)C resonance for the ring carbons of cellulose triacetate polymorphs. J Am Chem Soc 124: 75127518.

28. Kono H, Yunoki S, Shikano T, Fujiwara M, Erata T, et al. (2002) CP/MAS (13)C NMR study of cellulose and cellulose derivatives Complete assignment of the CP/MAS (13)C NMR spectrum of the native cellulose. J Am Chem Soc 124: 7506-7511.

29. Newman RH, Davies LM, Harris PJ (1996) Solid-State 13C Nuclear Magnetic Resonance Characterization of Cellulose in the Cell Walls of Arabidopsis thaliana Leaves. Plant Physiol 111: 475-485.
30. Habib HA, Hoffmann A, Hoppe HA, Janiak C (2009) Crystal structures and solidstate CPMAS $13 \mathrm{C}$ NMR correlations in luminescent zinc(II) and cadmium(II) mixed-ligand coordination polymers constructed from ,2-bis(,2,4-triazol-4-yl) ethane and benzenedicarboxylate. Dalton Trans 38: 1742-1754.

31. Noam A (1995) The Grotthuss mechanism. Chem Phys Lett 244: 456-462.

32. Tanaka K, Vega CA, Tamamushi R (1983) Mediation effects of ferric chelate compounds in microbial fuel cells. J Electroanal Chem Interfacial Electrochem 156: $135-143$.

33. McKinlay JB, Zeikus JG (2004) Extracellular iron reduction is mediated in part by neutral red and hydrogenase in Escherichia coli. Appl Environ Microbiol 70: 3467-3474.

34. Rabaey K, Verstraete W (2005) Microbial fuel cells: novel biotechnology for energy generation. Trends Biotechnol 23: 291-298. 